\title{
Overcoming Institutional Voids: A Reputation- Based View of Long Run Survival
}

\section{Citation}

Gao, Cheng, Tiona Zuzul, Geoffrey Jones, and Tarun Khanna. "Overcoming Institutional Voids: A Reputation-Based View of Long Run Survival." Harvard Business School Working Paper, No. 17-060, January 2017.

\section{Permanent link}

http://nrs.harvard.edu/urn-3:HUL.InstRepos:30000702

\section{Terms of Use}

This article was downloaded from Harvard University's DASH repository, and is made available under the terms and conditions applicable to Open Access Policy Articles, as set forth at http:// nrs.harvard.edu/urn-3:HUL.InstRepos:dash.current.terms-of-use\#OAP

\section{Share Your Story}

The Harvard community has made this article openly available.

Please share how this access benefits you. Submit a story.

Accessibility 


\section{Overcoming Institutional Voids: A Reputation-Based View of Long Run Survival}

Cheng Gao

Geoffrey Jones
Tiona Zuzul

Tarun Khanna

Working Paper 17-060 


\section{Overcoming Institutional Voids: A Reputation-Based View of Long Run Survival}

\section{Cheng Gao}

Harvard Business School

Geoffrey Jones

Harvard Business School
Tiona Zuzul

London Business School

Tarun Khanna

Harvard Business School

Working Paper 17-060 


\title{
Overcoming Institutional Voids: A Reputation-Based View of Long Run Survival
}

\author{
Cheng Gao \\ Harvard Business School \\ Tiona Zuzul \\ London Business School \\ Geoffrey Jones \\ Harvard Business School \\ Tarun Khanna \\ Harvard Business School
}

\begin{abstract}
Emerging markets are characterized by underdeveloped institutions and frequent environmental shifts. Yet they also contain many firms that have survived over generations. How are firms in weak institutional environments able to persist over time? Motivated by 69 interviews with leaders of emerging market firms with histories spanning generations, we combine induction and deduction to propose reputation as a meta-resource that allows firms to activate their conventional resources. We conceptualize reputation as consisting of prominence, perceived quality, and resilience, and develop a process model that illustrates the mechanisms that allow reputation to facilitate survival in ways that persist over time. Building on research in strategy and business history, we thus shed light on an underappreciated strategic construct (reputation) in an under-theorized setting (emerging markets) over an unusual period (the historical long run).
\end{abstract}

Keywords: Emerging Markets, Institutional Voids, Reputation, Business History, Intangible Resources 


\section{Overcoming Institutional Voids:}

\section{A Reputation-Based View of Long Run Survival ${ }^{1}$}

\section{Cheng Gao, Tiona Zuzul, Geoffrey Jones and Tarun Khanna}

\section{INTRODUCTION}

Emerging markets are characterized by institutional voids (Khanna and Palepu, 1997). To survive and thrive over time, firms operating in these markets must respond to unpredictable (but predictably frequent) shocks—-political instability, violence, macroeconomic fluctuations, and even war-without the benefit of specialized intermediaries that can analyze market information, facilitate transactions, and provide signals of credibility (Khanna and Palepu, 1997; Khanna and Rivkin, 2001). Doing so can be difficult and failure rates are high; for instance, emerging market banks had an estimated failure rate of 25 percent over a seven year period in the 1990s (Brown and Dinc, 2005). Nonetheless, emerging markets are rife with examples of firms and business groups that have survived over decades, generations, and even centuries. For example, Grupo Bimbo, founded in Mexico in the 1940s, endured national and international turbulence to emerge as one of the world's largest bakeries; Tata Group was founded in 1868 and developed into a leading Indian business group despite facing colonialism, rebellions, and major social transformations; and Koç Holding, founded in 1926, survived numerous national and regional crises to maintain its foothold as Turkey's

\footnotetext{
${ }^{1}$ A revised version of this paper is forthcoming in Strategic Management Journal. The authors would like to thank Gautam Ahuja, Ethan Bernstein, Yo-Jud Cheng, David Collis, Mauro Guillen, Budhaditya Gupta, Connie Helfat, Chris Kobrak, Daniel Malter, Chris Marquis, Rory McDonald, Leslie Perlow, Mike Pfarrer, Jan Rivkin, Amy Shuen, Laszlo Tihanyi, Anthea Zhang, Minyuan Zhao, two anonymous referees, and participants in the 2013-2014 HBS Seminar on the Craft of Inductive Qualitative Research, 2014 HBS Strategy Doctoral Students Seminar, 2015 ACAC PhD Research Development Workshop, and 2015 Academy of Management Annual Meeting paper session for helpful comments. The Division of Research and Faculty Development at the Harvard Business School kindly supported the research on which this paper is based.
} 
leading business group. Emerging markets thus present researchers with a puzzle: How are firms competing in such weak institutional environments able to persist across time?

Research in strategy has increasingly focused on the relationship between institutions and firm outcomes, proposing that effective strategies depend on and vary across different institutional environments (e.g. Ahuja and Yayavaram, 2011; Garcia-Canal and Guillen, 2008; Hiatt and Sine, 2014; Marquis and Raynard, 2015; Peng, Sun, Pinkham, and Chen, 2009). Scholars have argued that institutions are more than just background conditions (Meyer, Estrin, Bhaumik, and Peng, 2009), and directly influence the strategic actions available to an organization (Ingram and Silverman, 2002). In this view, firms can achieve and sustain competitive advantage through strategies that overcome, shape, and capitalize on the nature of their institutional environments (Marquis and Raynard, 2015).

Strategies that account for institutional environments might be especially important in emerging markets (Hiatt and Sine, 2014). Emerging markets are replete with institutional voids: they lack institutions that can help facilitate market transactions (Khanna and Palepu, 2010). Banks cannot always ensure access to credit; courts cannot guarantee the enforcement of intellectual property rights; auditors cannot reliably certify a firm's financial operations. As a result, the demands, constraints, and challenges facing firms in emerging markets are different than those facing their counterparts in mature markets. Theories and findings from developed market settings are not necessarily applicable in emerging market contexts (Khanna, 2014; Marquis and Raynard, 2015). Bettis, Gambardella, Helfat, and Mitchell (2014: 3) thus argued that there are "clear opportunities" to develop new theory for institutionally-underdeveloped settings in order to expand our understanding of "world-wide strategic management." This paper builds on one such opportunity.

Motivated by a set of 69 publicly available interviews with the founders and leaders of firms with histories spanning generations in emerging markets across continents, we 
combine induction with deductive reasoning to propose theory on how firms competing in institutionally weak settings are able to survive over the long run. Through an inductivedeductive theory-building process (c.f. Gavetti and Rivkin, 2007), we propose firm reputation as a key strategic construct in these settings. Driven by our data, we propose that in emerging markets, reputation consists of three elements: prominence, perceived quality, and resilience. The first two elements-prominence and perceived quality—have been established by research in developed markets (Rindova, Williamson, Petkova, and Sever, 2005). We extend this definition by proposing that a previously untheorized component-resilience (beliefs about a firm's ability to withstand shocks)—is essential in emerging markets. Our emerging markets research context allowed us to inductively uncover the importance of resilience, as the lack of institutional intermediaries in such settings sharply illuminated its significance. Particularly, in settings where a firm's survival cannot be taken for granted, and where institutional intermediaries cannot guarantee remediation, the belief that a firm will survive crises to fulfill its obligations is critical in driving stakeholder actions. Thus, by focusing on the context of emerging markets, we both build on and extend existing theory on the meaning of reputation.

We also propose a process model that illustrates the mechanisms that allow reputation to facilitate long-term survival. Because emerging markets feature institutional voids that hinder potential transaction partners from credibly signaling, accessing, and validating relevant information, a key structural feature that deters welfare-enhancing transactions between two parties is potential transaction uncertainty. In developed markets, counterparties can rely on mature institutions to decrease uncertainty and hedge against transactional risks, both by guaranteeing quality ex-ante, and by providing remediation ex-post. We propose that, when institutional credibility enhancers and adjudicators are not present, a firm's reputation can provide transactional confidence. This, in turn, can increase the quantity of profit-reaping 
transactions, allowing the firm to activate its conventional resources. This suggests that, in emerging markets, a positive reputation has cumulative effects: although a favorable reputation is difficult to acquire (and might even develop by chance), it can generate cascading positive feedback loops that can act as a source of sustained survival. We thus propose that reputation is a meta-resource, highlighting its higher-order ability to activate and moderate other resources (analogous to meta-routines ${ }^{2}$ and meta-knowledge ${ }^{3}$ ).

Our process model has implications for theory and practice. We contribute to research on emerging markets (e.g. Guillen, 2000; Henisz, Dorobantu, and Nartey, 2014; Khanna and Rivkin, 2001; Luo and Chung, 2013; Mair, Martí, and Ventresca, 2012; Siegel, 2007) by proposing reputation as a meta-resource that can help firms mitigate and capitalize on institutional voids to attain longevity. We also add to research on reputation as a strategic asset (e.g., Rindova et al., 2005). By deconstructing reputation into three components, theorizing the importance of resilience, and elaborating the mechanisms that connect reputation to survival, we build new theory on how this intangible asset might affect firm outcomes. More generally, our conceptualization of reputation augments theories of strategy suggesting that, in uncertain environments, successful firms enact continuous change (e.g. Eisenhardt and Martin, 2000; Helfat et al., 2009; Helfat and Peteraf, 2003; O’Reilly and Tushman, 2008; Rindova and Kotha, 2001; Teece, Pisano, and Shuen, 1997). We propose that in environments characterized by institutional voids, reputation provides the stakeholder buy-in that enables firms to engage in change.

We thus position reputation as a central concept at the intersection of strategy and emerging markets theory. By proposing a baseline theory of how reputation might affect survival, we hope to inspire future research that extends, refines, tests, and challenges our

\footnotetext{
${ }^{2}$ Higher-order routines for changing conventional routines; see Feldman and Pentland (2003).

${ }^{3}$ Knowledge used to differentiate between the hierarchical levels of knowledge types; see Evans and Foster (2011).
} 
hypotheses. For instance, although our data illuminated the importance and inter-related nature of three components of reputation—-prominence, perceived quality, and resilience-it did not allow us to disentangle the individual effects of these components. We thus focus our theorizing on the impact of reputation as a holistic construct, and hope to motivate research on whether and how these features are connected, conflicting, or reinforcing in driving outcomes in emerging market settings. Similarly, by focusing on long-lived firms in emerging markets, we propose mechanisms that connect reputation to survival for firms across both negative and positive economic cycles. We hope that future research on a larger sample of firms will build on these ideas to test whether (and how) more or less (favorable) reputation is connected to firm success or failure.

The remainder of this paper is organized as follows. First, we describe current theory on emerging markets. Next, we provide an overview of the relevant literature on reputation. We then outline the methods-an inductive-deductive approach-underlying our theory development. We develop a process model and a series of propositions, illustrated with interview quotes, that position reputation as a meta-resource that allows firms to mitigate and capitalize on institutional voids over time. We conclude by discussing the implications of these propositions for research in strategy.

\section{THE INSTITUTIONAL VOIDS OF EMERGING MARKETS}

Definitions of emerging markets vary. The term was first used by the International Finance Corporation in the early 1980 s to promote mutual fund investments in developing countries (Van Agtmael, 2007). Since then, various criteria have been used to define emerging markets, including GDP levels, poverty rates, stages of capital market development, and growth potential (Hoskisson, Eden, Lau, and Wright, 2000). Regardless of definition, emerging markets represent an important part of the global economic system: in the past 50 years, emerging markets have nearly doubled their share of world GDP, investment, trade, and 
private consumption. ${ }^{4}$ Advancing academic theory and knowledge of this setting has never been more relevant.

We follow Khanna and Palepu $(1997,2010)$ in defining emerging markets as "transactional arenas" where counterparties cannot easily or efficiently come together due to the absence of specialized intermediaries that support and facilitate transactions between buyers and sellers. Examples of such intermediaries include credibility enhancers (including auditors and third-party certifications), information analyzers (including credit ratings and Consumer Reports ratings), aggregators and distributors that provide low cost matching services (including banks, trading companies, and labor unions), transaction facilitators (including equity exchanges and platforms such as eBay), and adjudicators and regulators (Khanna and Palepu, 2010). These intermediaries are crucial for facilitating transactions in all markets, because information asymmetry and anticipation of transaction difficulties discourage contracting and exchange. Their absence results in high uncertainty: it is easier to engage in corruption or theft in an environment that lacks functional governance structures, independent checks and balances, transparent reporting standards, and efficient judicial adjudication systems (Hoskisson et al., 2000). Lack of effective political, governance, and regulatory institutions also increases the probability of instability and unrest in the very basic foundations of economic life, which further exacerbates the constraints to exchange. Hence, we define markets as "emerging" when institutional voids (an absence of intermediaries) leaves participants struggling to find ways to bring buyers and sellers together to engage in mutually productive exchange.

Our definition of emerging markets allows us to theorize beyond simply "developing countries," which research often equates with emerging markets, to all markets that have structural deficiencies due to institutional voids. While a majority of emerging markets today

\footnotetext{
${ }^{4}$ Rachman G. 2014. The future still belongs to the emerging markets. Financial Times 3 February.
} 
are located in developing countries, many contemporary advanced economies were once themselves emerging markets. An additional advantage of defining emerging markets in structural terms is that doing so allows us to avoid problems of tautology (defining emerging markets as emerging because they have not yet "emerged"), while also allowing for a variety of emerging market forms (Khanna and Palepu, 2010). That is, we conceptualize markets as falling along a continuum featuring different degrees of emergence: at one end, "dysfunctional" markets have an extreme degree of institutional voids, while at the other end, “developed" markets feature few institutional voids.

Strategy research on emerging markets has focused primarily on uncovering the drivers of short-term competitive advantage. One body of research has argued that when institutions are incomplete, incumbents, including business groups, dominate (e.g., Guillen, 2000; Khanna and Palepu, 1997; Khanna and Rivkin, 2001; Luo and Chung, 2005), although there is debate regarding whether this advantage is driven by value creation (Khanna and Yafeh, 2007) or value extraction such as tunneling or corruption (Morck, Wolfenzon, and Yeung, 2005). A related body of work has argued that dominant incumbents can gain competitive advantage through nonmarket actions that can mitigate political hazards, including lobbying (Choi, Jia, and Lu, 2014), stakeholder engagement (Henisz et al., 2014), and corporate social responsibility (Marquis and Qian, 2013). Network-based studies have examined the effect of political ties on outcomes (Zhu and Chung, 2014), and how such effects are moderated by institutional maturity (Shi, Markoczy, and Stan, 2014) and regime shocks (Siegel, 2007) that can transform network contacts from assets into liabilities.

While these studies have illuminated some of the factors associated with competitive advantage in emerging markets over the short or medium term, the drivers of long term survival remain comparatively undertheorized. For example, Khanna and Rivkin's (2001) analysis of business groups showing a positive association between group affiliation and 
performance was based on a dataset spanning approximately a decade. Henisz et al.'s (2014) study on stakeholder engagement employs a dataset spanning 15 years, one of the longest time spans for quantitative studies on this topic. There is little theory on whether mechanisms of competitive advantage are sustainable, replicable, and relevant to survival that persists over generations and centuries. As Jones and Khanna (2006) argued, for emerging market firms, history matters: their survival is dependent on factors and processes that allow them to endure shocks and crises over the long run. We therefore ask: how are some firms in emerging markets able to survive over the long term?

\section{REPUTATION IN EMERGING MARKETS}

Two primary bodies of literature have informed the definition of reputation as a strategic construct: an economic perspective, and an institutional perspective (Rindova et al., 2005). The economic perspective on reputation emphasizes its information signaling properties in the context of asymmetric information (Sorensen, 2014), and defines it as observers' expectations about a firm's attributes, and particularly its ability to generate high-quality products (Rindova et al., 2005). In this rational view, reputation is based on inferences from a firm's past actions (Weigelt and Camerer, 1988), and particularly its output quality (Allen, 1984; Clark and Montgomery, 1998; Shapiro, 1983). Complementing the economic perspective, the institutional perspective on reputation emphasizes the importance of social context. In this view, reputation comprises a set of collective beliefs about a firm, shaped partially through the evaluations of high-status institutions (Pfarrer, Pollock, and Rindova, 2010; Raub and Weesie, 1990; Rindova et al. 2005). In this view, high-status institutions, including industry analysts (Zuckerman, 1999), media establishments (Pollock and Rindova, 2003), and ratings certification contests (Rao, 1994), engage in evaluations that shape a firm's reputation in the eyes of other stakeholders. 
Drawing on both definitions, most strategy research on reputation is grounded in the resource-based view, suggesting that valuable, rare, inimitable, and non-substitutable resources generate competitive advantage (Barney, 1991; Peteraf, 1993; Wernerfelt, 1984). Strategy scholars have typically conceptualized reputation as one of a firm's many intangible resources. For example, Hall's (1993) taxonomy of competitive advantage argued that "reputation of products and company" alongside eight other intangible assets (including trade secrets, contracts and licenses, databases, know-how, and intellectual property rights) can lead to sustainable competitive advantage.

Research building on this view has suggested that a good reputation can strengthen while a bad reputation can harm a firm's performance (Fombrun and Shanley, 1990; Roberts and Dowling, 2002), and that firms that invest in and manage their reputations can gain a competitive edge over their rivals (Agarwal and Helfat, 2009; Rindova et al. 2005). Studies have suggested that a favorable reputation can help a firm realize the potential of its resources, enhancing its ability to attract and retain strategic human capital (Turban and Cable, 2003), lowering its cost of capital and increasing its ability to raise financing (Stuart, Hoang, and Hybels, 1999), increasing its ability to choose high quality partners (Dollinger, Golden, and Saxton, 1997) and form alliances (Stern, Dukerich, and Zajac, 2014), and helping mitigate the impact of negative events (Love and Kraatz, 2009). Reputation, signaled through institutional intermediaries such as credibility enhancers, can also reduce transaction costs (Williamson, 1981) for a firm by ameliorating a transaction partner's concerns about the firm's propensity to engage in opportunism

Antecedents of reputation include a firm's financial performance and management practices (Staw and Epstein, 2000), the frequency of its market actions and complexity of its repertoire (Basdeo, Smith, Grimm, Rindova, and Derfus, 2006), its responses to layoffs and downsizing (Flanagan and O’Shaughnessy, 2005), and changing management fashions 
(Bermiss, Zajac, and King, 2013). Firms can manage and exploit reputation through brands. To assess reputation, buyers "tend to use brand names as signals of quality and value and often gravitate to products with brand names they have come to associate with quality and value" (Herbig and Milewicz 1995: 8). Brands can even induce economies of scale in generating and spreading reputation; for example, a firm with a favorable reputation due to high quality performance in one product can transfer that positive reputation to another product via its brand name (Moorthy, 1985).

Strategy research on reputation has primarily focused on, and was developed in, the context of mature markets. There is limited research on how reputation functions in emerging markets. What dimensions of reputation are important in emerging markets? Is it one of many intangible resources affecting outcomes? Or does it interact with other resources in patterned ways that can lead to success or survival? Even the fundamental assumptions about the ways reputation operates are not necessarily met in settings replete with institutional voids. For example, is perceived quality a key dimension, as the economic view would suggest, in settings where a firm's ability to abide by its agreements or withstand future shocks might be in question? Emerging markets by definition lack the institutional intermediaries that help shape collective perceptions, a core assumption of the institutional perspective on reputation (Rindova et al., 2005: 1034) and even of transaction cost economics (Williamson, 1981). How does reputation operate, given a lack of intermediaries such as credibility enhancers and information analyzers (Khanna and Palepu, 2010)?

One area of research that has explored reputation in the context of emerging markets is business history. Business historians have examined emerging markets from the broad arc of history (e.g., Jones, 2005; Jones, 2013), and have begun to suggest the importance of reputation in allowing firms to achieve sustained, long run success (e.g., Kobrak, 2013; McKenna and Olegario, 2012; Olegario and McKenna, 2013). For instance, Jones' (2000) 
historical analysis of British multinational trading companies from the eighteenth century to the present day suggested the firms' reputations helped them withstand long run shocks and change their strategies over time. Connell's (2004) research on the long run survival of the Jardine Matheson trading group demonstrated how the group's reputation was leveraged to take advantage of various perceived opportunities. And Pak's (2013) study on J.P. Morgan showed how in the early twentieth century-a time when the U.S. was an emerging market-J.P. Morgan's reputation played a crucial role in facilitating transactions in private banking, a secretive world characterized by little public information. However, the historical conceptualization of reputation as a key driver of long run survival is undertheorized in strategy.

\section{DATA AND METHODS}

We develop our contribution through an approach that combines inductive and deductive reasoning, an analytical process different than that typical of inductive, qualitative research (see Lounsbury and Glynn, 2001; Rindova, Pollock, and Hayward, 2006; Gavetti and Rivkin, 2007 for other examples of similar methods). Our theory was motivated by an analysis of 69 interviews with the founders and leaders of firms featuring histories spanning an average of 73 years, in emerging markets across Central and South America, Africa, South Asia, and the Middle East. Inductive analysis of the interviews revealed the importance of reputation, and suggested initial ideas about how it might promote long term survival in emerging markets.

However, given some limitations of the data, and the stock of existing research on reputation and on emerging markets, we engaged in deductive theory-building to develop a process model encompassing both insights from prior research and those first gleamed through the interviews. Our aim is building rather than testing theory: the proposed model can be further refined and validated empirically in future studies.

\section{Data}


We analyzed a set of 69 semi-structured interviews, typically ranging from one to two hours, publicly available as part of the "Creating Emerging Markets" project of the Business History Initiative at Harvard Business School. ${ }^{5}$ The respondents were current and former leaders at the CEO, Chairman, or Founder level of top emerging market firms. The mean and median age of both the firms and respondents in our sample at the time of interview was close to 70 years (see Appendix 1 in the online supplement for a full list of firms, respondents, their positions, and summary statistics of the dataset).

The firms were selected through a systematic process that started with identifying the top business firms in a particular emerging market. For each country, a team of academic researchers polled between three and ten country experts (determined by the size of the country) to identify a list of top firms with a living founder or elder leader that has led the firm for at least a decade, and in many cases, multiple decades. By "top firms," the researchers referred to firms that have survived over the long run, rather than firms with the highest current performance in their industries. Common firms across these different lists were then discussed, and cross-checked with publicly available rankings of the top firms in a country, to generate a final list of sampled firms. During the deliberation process, the researchers targeted respondents over 60 years old to not only reduce respondent bias (older respondents could be more frank since their words no longer affected their career prospects), but also to capture leaders' and firms' responses to the many changes—both good and bad-that had occurred in their firms and their emerging markets over the past several decades. The researchers sent out interview requests to a final list of firms; remarkably, the requests were never declined except for logistical reasons (some interviews took several years to schedule and execute, sometimes due to the health issues of the respondents).

\footnotetext{
${ }^{5}$ Full data citation listed in the references section. Website: http://www.hbs.edu/businesshistory/emergingmarkets
} 
The interviews were conducted by a set of professional academic interviewers, trained to follow best practices (including asking non-leading questions, and probing for detail where appropriate). When possible, the researchers travelled to the respondents' offices to conduct the interviews so that respondents would feel at ease. The interviews began with open-ended questions asking the respondent to describe his or her firm's development from inception to the present, focusing on the respondent's own experiences in leading the firm. The questions were carefully worded in order to avoid guiding the respondent down any particular path. Open-ended questions were followed-up with specific questions to explore the "hows" and "whys" behind each critical issue, decision, or action that the respondents described.

Notably, the researchers conducting the interviews were blind to the purpose of their use in any future studies. This is a strength of our research design and unique in qualitative studies, as it reduces potential sources of interviewer bias (including by attenuating the possibility of confirmation bias). In particular, the interviews were conducted without a focus on reputation as a topic of inquiry - its importance emerged inductively from the data.

We chose to analyze this data set for several reasons. First, the interviews - to our knowledge, the largest set of in-depth academic interviews with the leaders of top firms across the world - provided rare access to the leaders of emerging market firms. In fact, in many cases, these interviews were the first academic research interviews granted by the respondents in their entire careers. They thus provided an opportunity to draw on executives' perspectives to develop theory on the mechanisms underlying firm activities in emerging markets, especially important given the dearth of both quantitative and qualitative data in this context writ large. ${ }^{6}$

\footnotetext{
${ }^{6}$ In fact, the lack of systematic data (quantitative and qualitative) was the motivator of the "Creating Emerging Markets" data collection project.
} 
Second, the data provided a unique "theoretical sampling" of the top firms in emerging markets. ${ }^{7}$ The firms and respondents were chosen because of their long histories; they thus represent "unusually revelatory, extreme exemplars" (Eisenhardt and Graebner, 2007: 27) of long-lived firms. Theoretical sampling - particularly of extreme cases (whether notable failures or successes) - is a useful tool for building theory, because it allows researchers to generate insights that might be obscured or absent in typical settings or in large-N, comparative studies (Eisenhardt and Graebner, 2007; Pratt, 2009; Eisenhardt, Graebner, and Sonenshein, 2016). By examining firms with long histories, including periods of success and failure, we hoped to uncover processes that appeared connected to survival, with special attention to the mechanisms that were replicated across multiple cases; our aim was not to propose constructs that explained variance in outcomes. This allowed us to respond to calls for theories on how firms can overcome, and survive, in challenging emerging market contexts-an underdeveloped area of research due to the challenges of obtaining emerging markets data. ${ }^{8}$

Finally, the data provided a high level of transparency and reproducibility. Because the interview transcripts are available from the Business History Initiative website for direct download, our data is transparent and our inductive process is replicable. This is highly unusual in qualitative studies, since full interview transcripts and field notes are usually not available to other scholars.

\footnotetext{
${ }^{7}$ Theoretical sampling - that is, the selection of a set of cases based on a theoretical similarity (for instance, a particular organizational configuration (e.g. Battilana and Dorado, 2010), industry and firm age (e.g. Santos and Eisenhardt, 2009), and similar history of success (e.g. Dougherty and Hardy, 1996)) - is commonly employed as the sampling method of choice in research aimed at developing theory. Indeed, because theoretical sampling allows for constant comparison of the processes underlying similarities, it is considered "more important than statistical sampling in an exploratory qualitative study" (Kram, 1983: 611).

${ }^{8}$ On one hand, research examining top firms in this setting typically consists of teaching-oriented case studies, which tend to focus on determinants of success in extreme cases at a particular static point in time (e.g. Ghemawat 2007; Ghemawat and Siegel, 2011). On the other hand, academic work on emerging markets typically comprises large-N quantitative studies that focus on estimating average industry effects of a particular determinant of success (e.g. Douma, George, and Kabir, 2006; Henisz et al., 2014; Khanna and Rivkin, 2001; Tan and Peng, 2003).
} 
Of course, the nature of the data also brings up potential limitations. Despite the benefits of theoretical sampling, our choice to analyze firms that have survived over the long run might make it difficult to develop generalizable theory. However, the firms in our sample have experienced both successes and failures in the wide sweep of their histories. Their leaders' appreciation of reputation comes from their exposure to both good and bad times. In the interviews, leaders often mentioned the challenges they had faced, the failures they had experienced, and the mistakes they had made. In other words, there was significant variation in performance within the firms' individual histories, and our theory development benefitted from this heterogeneity. In addition, the use of retrospective and public data brings up concerns about respondent bias, including retrospective bias and impression management (Golden, 1992). However, given the seniority of the respondents, the elapsed time between the interviews and the events described helped foster greater candor and openness by the respondents, as interviews generally no longer affected the respondents' careers. Nonetheless, we addressed these concerns by combining inductive analysis with deductive theory-building, as elaborated below.

\section{Inductive data analysis}

Given the paucity of research on how firms sustain longevity in emerging markets, we began by engaging in inductive analysis to identify constructs that our respondents believed were critical for survival over time (Edmondson and McManus, 2007). We started our analysis with no a priori theoretical preferences or hypothesis, following the principles of a grounded approach (Corbin and Strauss, 2008; Charmaz, 2014). Our goal was to identify within and across our interviews the patterns, processes, and relationships that appeared connected to survival. We coded the interviews, using the qualitative data analysis software QSR-NVivo to organize our codes, and developed an emergent set of first-order codes that appeared related to success across time and multiple cases. Examples of such codes include 
professionalization, diversification, political activity, and brands. We then engaged in repeated cycles of coding, iterating between coding and writing analytical memos, to adjust, refine, and cluster the first order codes into second-order theoretical categories, or themes (Corbin and Strauss, 2008). (See Appendix 2 in the online supplement for our data structure).

Through this process, we recognized the importance of a second-order theme we conceptualized as "reputation." Although never directly asked about reputation, leaders often either mentioned reputation explicitly, or discussed mechanisms and processes related to firm prominence, perceptions of quality, and resilience. (See Appendix 3 in the online supplement

for examples). After iterating between the data and existing theory, we realized that what the respondents were describing most closely matched theoretical conceptualizations of firm reputation. We sharpened our analysis to explicate an anatomy of reputation.

\section{Deductive theory-building process}

At this stage, given the constraints of the data and the stock of existing research on reputation and emerging markets, instead of developing theory by solely relying on our inductive analysis, we stepped beyond the interviews and engaged in a deductive theory-building process by synthesizing the emergent theme of reputation with the academic literature. This involved developing the category of reputation to deductively consider, in theoretically generalizable ways, how it might shape long term survival. That is, while the interviews motivated our focus on reputation, we developed our propositions by leveraging resourcebased theories of competitive advantage as well as a stream of research in business history that has suggested the importance of reputation in emerging economies in earlier historical periods, including the $18^{\text {th }}$ to $20^{\text {th }}$ centuries. We iterated between the interviews, findings, and this literature to refine our theory development. This cycle of analysis eventually resulted in our proposed conceptualization of reputation as a meta-resource that drives resource activation in emerging markets. 


\section{A REPUTATION-BASED THEORY OF LONG RUN SURVIVAL IN EMERGING MARKETS}

Emerging markets are characterized by high potential transaction uncertainty. Because emerging markets lack intermediary institutions that provide, analyze, and certify information, there is great uncertainty regarding a firm's propensity to abide by its promises, and even its future existence. We conceptualize reputation as a construct that provides firms with transactional confidence that overcomes this potential transaction uncertainty through both defensive and offensive mechanisms. We propose that these mechanisms increase the quantity of firm transactions: defensive mechanisms can provide a firm more time to exploit existing business opportunities, while offensive mechanisms can allow a firm to capture new business opportunities. We propose that these mechanisms are valuable during both negative and positive economic cycles; the increased transactions they engender can allow a firm to activate its existing conventional resources in order to fulfill transactions. Synthesizing these findings, we propose that reputation functions as a meta-resource that activates and moderates conventional firm resources. Finally, we suggest that reputation has cumulative effects-driven by the difficulty of acquiring reputation and the reinforcing mechanisms atplay once reputation is acquired-and propose that reputation can function as a potential source of persistent survival.

\section{[ INSERT FIGURE 1 AROUND HERE ]}

\section{The challenge of emerging markets: potential transaction uncertainty}

Emerging markets are characterized by high levels of potential transaction uncertainty that can prevent economic transactions (Khanna and Palepu, 2010). For example, Arturo

Acevedo, President of Grupo ArcelorMittal (Acindar), reflected:

"Lack of predictability in Argentina creates uncertainty and this drives companies' unwillingness to commit resources." 
Across the interviews, potential transaction uncertainty generally took one of two main forms. One was counterparty behavioral uncertainty. A lack of information regarding counterparties and weak institutions for contract enforcement and adjudication created uncertainty regarding whether a firm would abide by the terms of an agreement, including the quality of the output to be exchanged, the timeliness of fulfillment, and the probability of reneging. This behavioral uncertainty constrained potential transactions. For example, Jose Grana Miró Quesada, Chairman of Graña y Montero (a Peru-based construction and real estate group), noted how a lack of information on whether a counterparty would submit payment for a potential project ultimately prevented the project from occurring. He recalled:

"We won a bid for a bridge...We signed the contract, but [the counterparty] wouldn't make the advance payment. I remember [the President of Peru] called me and complained, asking why we weren't working yet. I told him, 'Mr. President, we haven't received the down payment. How could we start working?' ...That bridge was never built."

In another example, Dionisio Garza Medina, Former President and CEO of Alfa S.A.B. (a multinational Mexican business group), recalled how a multinational business partner, AT\&T, lost faith in its joint telecom investments in Mexico after its other partners ignored or obstructed the terms agreed to in contracts. There was little AT\&T could do in response, due to the lack of independent legal institutions, an insidious institutional void:

"[After a promised telecommunications reform] we partnered with AT\&T, with the dream that the business was going to grow significantly...We invested one billion dollars between both companies... Then we realized that what was written in the law was not going to be enforced in real life...The President of AT\&T said, 'In your country I will not spend another cent, because laws are not enforced' "

Another type of transaction uncertainty was environmental uncertainty: even when both parties to a transaction acted according to their agreements, frequent environmental shocks (including regulatory and political shocks, expropriation, coups, chaos, wars) still posed a threat. For example, Arturo Acevedo, President of Grupo ArcelorMittal-Acindar (the leading producer of long carbon steel in Argentina), recalled: 
"The second crisis, which I consider the toughest, was the 1978-1981 period, the time of the guerrilla-military war in Argentina... All plants along that strip were deeply affected. The guerrillas killed several of our managers and took over our plants, and the military would walk into our plants to get guerrilla fighters out. It was a terrible time."

Because of these shocks, firms faced the risk that their operations - or the operations of their partners, suppliers, and buyers - would cease to exist or become severely disrupted. For example, Dionisio Garza Medina (CEO of Alfa S.A.B.) recalled:

"In 1979 I was full of dreams and aspirations...In 1981, I was in technical bankruptcy... [This was] a period of high interest rates... Mexico suffered devaluation... There was high inflation; the interest rates went up from $5 \%$ to $15 \%$, devaluation of the peso, price controls: we [thought we] were dead!"

The constant possibility of debilitating environmental shocks such as negative regulatory actions often weighed heavily on firms in emerging markets. For example, Hakeem Belo-Osagie, Chairman of the Nigeria-based United Bank for Africa (one of Africa's leading multinational financial institutions), emphasized how the burden of managing against political risks and regulatory uncertainty in the absence of institutions required dedicating significant organizational resources and constant attention:

"The biggest challenge in Africa...is that you constantly have to manage... the regulatory agencies... Things can go horribly wrong if you do not manage that aspect very well."

In the examples above, the challenge for each firm, as its leaders described, was mitigating potential transaction uncertainty. To engage in exchanges, customers and partners had to believe that the firm could overcome both behavioral uncertainty (that it would act in accordance with agreements) and environmental uncertainty (that it would withstand shocks and ensure business continuity). In developed markets, credible information analyzers and verifiers as well as stable and independent regulatory, political, and legal institutions help mitigate such concerns. In emerging markets, firms have to overcome potential transaction uncertainty to engage in business despite the absence of such institutions.

\section{Reputation provides transactional confidence}


We propose that a firm's reputation can help to both overcome and capitalize on transaction uncertainty. Voids in institutions ensure that in emerging markets, there is no guarantee that a firm will abide by its agreements, or continue to operate in the face of environmental shocks. To engage in transactions with a firm, stakeholders have to believe the firm will both honor its promises and withstand shocks. A favorable reputation can act as a credible signal that helps mitigate uncertainty and provides transactional confidence. We propose that, in emerging market settings, reputation consists of prominence, perceptions of quality, and resilience.

For instance, Savannah Maziya, group CEO of Bunengi Holdings (one of Africa's leading infrastructure and mining conglomerates), emphasized how the firm's success in its first mining project led to prominence that cascaded into enormous opportunities over time:

"I think getting our first mine was a game-changer...Then that just leapt into other projects and leapt into other opportunities. We are today who we are based on that first project, because it proved to everybody...that we could do this kind of business."

\section{Guillermo Murchison, CEO of Murchison S.A. Estibajes y Cargas (a large port} services and warehousing firm based in Argentina), summed up the importance of a reputation for quality of products, behaviors, and adherence to promises in operating in an environment replete with institutional voids:

"They [clients] trusted me; they knew we always did everything the right way. The company still enjoys a great reputation. People value those things."

Finally, Antonio Madero (Founder, Chairman and CEO of Sanluis Corporation, a leading Mexico-based automotive parts maker), emphasized the importance of having a reputation for resilience, or the ability to withstand challenging and unexpected shocks, built through the firm's response to prior challenges:

"After the crisis of 2009, the orders increased and our growth rate over the following 5 years is 21 percent per year. Why? Because we have the trust of our clients who saw how we managed to overcome the crisis." 
Keshub Mahindra, the former Chairman of the Mahindra Group (a leading multinational Indian business group), echoed this sentiment, noting that the firm's reputation stemmed from the fact that stakeholders saw, "in spite of very difficult conditions, we are able to do business.” In emerging markets, perceived resilience is critical because a firm's continual existence is certainly not something taken for granted. As Arturo Acevedo, President of Grupo ArcelorMittal, noted:

"Argentina is a very unpredictable country... and we are managing to survive, which is certainly no easy thing."

As the above quotes illustrate, firms with prominence, a reputation for delivering quality products and engaging in quality behaviors (including honoring agreements), and having resilience (including surviving prior environmental challenges), can build transactional confidence. We thus offer the following proposition:

Proposition 1: In emerging markets, a favorable reputation - comprising prominence; beliefs about quality; and beliefs about resilience - can help firms overcome and capitalize on informational voids by reducing potential transaction uncertainty.

\section{Transaction confidence operates through defensive and offensive mechanisms}

We propose that, by providing transactional confidence, reputation affects firm outcomes through two mechanisms. By reducing potential transaction uncertainty, a favorable reputation can allow a firm to (1) overcome institutional voids by buffering against threats (the defensive mechanism); and (2) capitalize on institutional voids by generating new opportunities (the offensive mechanism).

Defensive mechanism: Buffering against threats

First, a favorable reputation can buffer a firm against threats by allowing for flexibility in its responses. By providing transactional confidence, a favorable reputation can convince counterparties that a firm is acting in an appropriate and trustworthy way. In emerging markets, firms will have to adapt in response to threats and shocks to survive; a 
favorable reputation can ensure adaptations are not seen as signals of behavioral drift that dissuade future transactions.

For example, when the Mahindra Group's auto division had to lay off 500 people due to weak demand, there were no riots or turmoil because the community trusted that there must have been a good reason for the layoffs, given the reputation that the Mahindra Group had cultivated with the local community over time. This was despite India's history of industrial strife, often marked by labor union militancy. A riot or turmoil would have severely disrupted the Mahindra Group's ability to exploit its business model and engage in transactions. Keshub Mahindra, former Chairman of the Mahindra Group, contrasted his firm's peaceful layoff against another factory's more turbulent layoff that was marked by resentment-fueled strikes. He emphasized how the group's favorable reputation allowed it to buffer against a demand shock by giving it more flexibility and leeway to adapt and operate:

"Last week, we laid off 500 people because of [low] demand in the auto industry. Apart from a little thing in the papers, no one cared because...they trust us. They know that we would not have done this unless we had good reasons. The building of trust and confidence has been our most useful tool."

Julio Werthein, Founder of Grupo Werthein (one of the largest diversified business groups in Argentina), also emphasized how his firm's reputation shielded it from domestic crises that lowered general investor trust in Argentina. When asked whether domestic crises jeopardized his operations abroad, Werthein emphasized that: "That was no problem, because people trusted our management." As the quotes illustrate, in emerging markets, a firm's reputation can allow it to respond to threats without inspiring stakeholder doubts about its intentions or its future trajectory. ${ }^{9}$

Offensive mechanism: Capitalize on new opportunities

\footnotetext{
${ }^{9}$ Another example that underscores this point is Khanna, Palepu, and Herrero's (2007) case study on Tetra Pak Argentina, a multinational food packaging and processing company of Swedish origins. When the Argentinian currency collapsed, Tetra Pak was still trusted by the market due to its favorable reputation as a firm that acted in accordance with its promises. As the case notes, this played a key role in its survival.
} 
Second, a favorable reputation can allow a firm to attract new customers and partners, and thus generate new opportunities. For instance, Adi Godrej, Chairman of the Godrej Group (one of India's largest diversified business groups) described how the group was able to leverage its reputation to enter into transactions with customers in new industries:

"We did... better than most Indian businesses because we were among the few [that] had a strong brand...we used the family name...in the branding. Our cupboards were called Godrej Cupboards, our refrigerator was a Godrej Refrigerator, and our locks were Godrej Locks... So the Godrej brand ran across many categories... it became a well-known name. For example, our real estate development business has leveraged the brand strength very well. That helps us considerably."

A favorable reputation can also allow firms to develop relationships with new partners.

For instance, Suresh Krishna, chairman of Sundram Fasteners (the largest maker of industrial fasteners in India and a constituent company of TVS Group, one of India's leading industrial business groups), recalled the importance of reputation from his affiliation with TVS group that allowed him to get his "foot in the door" when he first launched Sundram Fasteners. Despite having the technological capabilities, it was the reputation of TVS, a trading and distribution oriented business group, that allowed Krishna to gain the access to transaction partners to exploit his technology and resources and thus successfully build a manufacturing oriented business. Krishna recalled:

"It was a great platform. TVS had already been in existence for 50 years in $1962 . .$. That helped a lot in at least getting your foot into the door... Saying they knew who I was, and they knew TVS meant something. I didn't have to explain the group; everybody knew the group. It was a tremendous advantage. The minute they saw TVS, they'd say, 'Okay,' and all doors opened....If I had been an independent, stand-alone, fresh out of school entrepreneur, I think the journey would have been 100 times more difficult."

Additionally, Fazle Hasan Abed, the founder and Chairman of BRAC (a Bangladeshbased development organization that is the largest NGO in the world by number of employees), emphasized that BRAC's positive reputation was instrumental in facilitating growth from Bangladesh into new geographies worldwide. 
"We have a reputation of being able to deliver whatever we promise, and that helps us...As soon as we went to Afghanistan [from Bangladesh] in 2001, everybody flocked to fund BRAC, because we had the reputation."

In the examples above, leaders emphasized that the extent to which they capitalized on an opportunity — whether in a new market or with new partners — depended on how much counterparties (businesses or consumers) knew them, trusted the quality of their products and behaviors, and believed in their ability to overcome shocks and crises. This notion is consistent with studies showing that business groups with strong reputations are most likely to capitalize on new opportunities that emerge during policy shocks that result in market liberalization (Khanna and Palepu, 1999; Ghemawat and Khanna, 1998).

Thus, we propose that in emerging markets, reputation-by reducing transaction uncertainty-buffers firms against threats, and enables them to capitalize on new opportunities. We summarize this in the following two-part proposition:

Proposition 2a: In emerging markets, by reducing potential transaction uncertainty, a favorable reputation buffers a firm against threats.

Proposition 2b: In emerging markets, by reducing potential transaction uncertainty, a favorable reputation enables a firm to capitalize on new opportunities.

\section{Defensive and offensive mechanisms increase quantity of transactions}

We propose that the defensive and offensive mechanisms of reputation increase the quantity of a firm's transactions, allowing a firm to activate its conventional resources. ${ }^{10}$ By buffering against threats, the defensive mechanism can provide a firm with more time to exploit existing business opportunities, increasing its quantity of transactions. For example, the Mahindra Group's reputation provided the firm with time to exploit its business opportunities, even when other firms in India were unable to do so. Keshub Mahindra noted:

"Overseas, when you have a fall in demand you can lay off people.... In India, you can hardly ever do that, so even if you are facing a low-demand situation, you are stuck with the cost of labor."

\footnotetext{
${ }^{10}$ For simplicity, we focus on quantity and abstract away from the potential impact on the "quality" of a firm's transactions. For brevity, we can think of a notion of "quality-adjusted" quantity, which we do not explore in this study but see as a promising area for further research.
} 
In this case, Mahindra Group's favorable reputation uniquely allowed it to adapt to negative demand conditions by laying off people, so that it could continue to operate and exploit its business model to increase transactions. In contrast, competitors without such a favorable reputation would be greatly constrained from adapting via layoffs, since labor union militancy in response to a layoff could severely disrupt operations.

By allowing a firm to capture new business opportunities through attracting new customers and partners, offensive mechanisms can directly increase the quantity of transactions that a firm captures. More transactions to execute means greater utilization of

otherwise idle resources. For example, when Godrej Security Safes leveraged its reputation to move into the refrigerator sector, new refrigerator orders meant Godrej had to increase its utilization of its conventional resources in order to fulfill these new transactions.

We thus propose that these mechanisms allow firms to increase the quantity of their transactions under both positive and negative macro-economic conditions. The leaders interviewed had steered their firms through positive and negative times, across periods of economic boom and bust. During challenging economic cycles, the defensive mechanism allowed their firms to engage in adaptation, including downsizing, without compromising stakeholders' confidence. During times of boom, the offensive mechanism allowed the firms to attract new customers, partners, and engage in further expansion. We summarize this in the following proposition:

Proposition 3: In emerging markets, by buffering against threats and allowing for new opportunities, a favorable reputation increases a firm's quantity of transactions.

\section{Reputation as a meta-resource that moderates conventional resources}

We thus propose that reputation is a meta-resource that moderates the degree to which a firm can activate its conventional resources. In emerging markets, because high potential transaction uncertainty discourages transactions, having strong inputs and capabilities for 
producing output is not enough to ensure a firm will attract customers and partners. We suggest that, unless a firm is able to leverage its reputation to attract counterparties in the absence of institutional guarantors, its resources and capabilities-no matter how powerful—will remain idle and unused. This notion was succinctly summed up by Rahmi Koç, Chairman of Koç Holding (Turkey’s largest diversified business group):

"Perception is most important. You can have good items, but if your brand is not associated with quality and history, you do not get satisfactory margins."

As this quote illustrates, the inter-related nature of reputation's underlying components prominence (in Koç’s words, “perception”), perceptions of quality (“quality”), and resilience ("history") — can facilitate survival.

We conceptualize reputation as a meta-resource because of its high order ability to activate, leverage, and moderate other resources. The use of the "meta" label is analogous to work on organizational routines differentiating between lower-order operative routines and higher order decision procedures - meta-routines - consisting of routines for changing conventional routines (Feldman and Pentland, 2003). Similarly, in evolutionary economics, meta-routines are viewed as the genes of an organization-higher-order routines that affect, constrain, and influence generic firm activity patterns (Nelson and Winter, 1982). We summarize this idea with the following proposition:

\section{Proposition 4: In emerging markets, a favorable reputation acts as a meta-resource} that allows a firm to activate its conventional resources.

\section{Cumulative effects: Reputation as a basis for long run survival in emerging markets}

Having proposed the ways that reputation enables firms to overcome and capitalize on institutional voids in volatile institutional environments, our hypotheses give rise to an additional question: if reputation is so important, how can it be a source of sustained survival? In other words, why should there exist a heterogeneous distribution of reputation across firms, instead of a situation of competitive parity, where all firms invest in reputation 
and thus with competition the heterogeneity in reputation disappears over time? Reconciling insights from the interviews with theories of competitive advantage, and the resource-based view in particular, we propose that reputation has persistent and sticky effects because, first, acquiring reputation without an extant base of reputation is exceedingly difficult, and second, once acquired, reputation begets more reputation.

First, we suggest that, to acquire reputation, firms not only have to be able to produce good quality output, but also needed to focus on managing perceptions of resilience. That is, firms have to convince stakeholders that they are likely to persist and thrive over time. For example, Rafael Guilisasti Gana, Vice Chairman of Viña Concha y Toro (Latin America’s top producer of wine), noted the complexity involved in building reputation. As his statement indicates, doing so involved not just making quality wines, but also influencing stakeholder perceptions of the firm as one deeply embedded in its industry and value chain:

"To meet that requirement, you need to make quality wine... but... it's not just about explaining quality, but also about aspiring to international recognition and endorsement-not from consumers themselves, but from the entire distribution chain: wine critics, restaurants and on- premise consumption."

Acquiring reputation without an extant base of reputation is likely to be difficult.

Research suggests that it may involve contributions to the public good. Because this process is complex, time consuming, expensive, and require expertise to execute, it may be difficult to imitate (e.g., Henisz et al., 2014; Khanna and Palepu, 2004). Often, a firm’s early reputation may thus emerge through luck. For example, Adi Godrej (Chairman of the Godrej Group) noted that the reputation of the Godrej name was actually initially propelled by a lucky shock:

"We were helped tremendously by a major explosion in the Bombay docks during the Second World War. There was a ship carrying ammunition which exploded in the docks, and it created major damage in the Fort area of what was then Bombay. A lot of offices suffered destruction and many of the British safes were destroyed, whereas almost all the contents of our safes were perfectly alright. And that led to great success later for our safe business." 
After this, Godrej noted that the Godrej name became well-known, and because of its reputation for quality, the firm was able to successfully expand its product portfolio into many new and different industries. This example not only illustrates the role that luck often plays in bestowing reputation, but also suggestively highlights the causal direction of reputation in affecting outcomes.

Although it might be difficult to acquire initially, we also propose that, once initiated, reputation can be reinforced in cascading positive feedback loops. Having a favorable reputation might lead to more opportunities, which can further increase reputation, which can lead to even more opportunities, and so on. For example, Antonio Madero, Founder, Chairman and CEO of Sanluis Corporation, noted how having a level of favorable reputation helped build more reputation via self-reinforcing positive feedback loops:

"Everything is public in the business world. If you are successful in your own business...then you acquire an outstanding reputation... and people will pay attention to what you have to say...We are growing in what we do globally; we are adding product lines directed toward the same type of customer because we already have a very good reputation."

Thus, acquiring and developing reputation is likely to be a time dependent and socially complex process. While this might make reputation difficult to acquire, it also suggests that reputation is potentially a durable source of sustained advantage (Barney, 1991; Peteraf, 1993). Moreover, the potentially reinforcing nature of reputation underscores its importance in emerging markets. As its effects compound over time, reputation can build ever-growing confidence that a firm will overcome institutional voids; that is, over time, reputation can become an increasingly credible signal reducing potential transaction uncertainty. We thus propose that a firm's reputation can serve as a core basis of strategy for competing in emerging markets. We synthesize via the following proposition:

Proposition 5: In emerging markets, a favorable reputation can be a source of long term survival. 


\section{DISCUSSION}

In this paper, we theorize reputation as a driver of long term survival in emerging markets.

We propose that, in emerging markets, a favorable reputation can act as a meta-resource that moderates whether a firm can activate its conventional resources, and illuminate the mechanisms that connect reputation to long run survival. Specifically, we propose that reputation is crucial for survival in emerging markets, because it allows firms to overcome and capitalize on the transaction uncertainty created by institutional voids. We propose that reputation is a unique strategic construct in emerging markets in that, through its offensive and defensive channels, it can be beneficial regardless of whether a firm is on the upswing or downswing of a volatile cycle. Furthermore, reputation's socially-complex and intangible nature implies both a high barrier to imitation and reinforcing feedback loops that facilitate increasing returns over time; we propose that reputation can thus allow firms to survive and persist over generations.

In developing this theory, we contribute to a growing literature on institutional voids in emerging markets (e.g. Guillen, 2000; Henisz, Dorobantu, and Nartey, 2014; Khanna and Rivkin, 2001; Luo and Chung, 2013; Mair, Martí, and Ventresca, 2012; Siegel, 2007). Our conceptualization of reputation as a meta-resource provides a mechanism-based view into one way that institutional voids might be mitigated and leveraged as a source of advantage. At a more general level, we contribute to knowledge on how intangible assets affect organizational outcomes, responding to Pfarrer et al.'s (2010: 1145) call for scholars to develop theory that "precisely specify and capture the type of intangible asset studied and the context within which its effects are investigated" in order to gain "greater insights into the mechanisms through which intangible assets provide competitive advantages." In so doing, we augment existing theories of strategy that stress the importance of continuous change. For example, research on the importance of dynamic capabilities emphasizes that firms can adapt 
to changing environments across time by changing, organizing, and recombining resources, capabilities, and routines (e.g. Teece, Pisano, and Shuen, 1997; Eisenhardt and Martin, 2000; Rindova and Kotha, 2001; Helfat and Peteraf, 2003; Helfat et al., 2009). We propose reputation can be an antecedent that allows firms to engage in change. We suggest that reputation, at its core, provides stability (maintaining a favorable reputation engenders transactional confidence due to the stable informational cues it provides); we propose that it is this very stability that provides a spring-board for firms to reorient resources to adapt to a changing environment. The example of the Mahindra Group illustrates this idea: when Mahindra had to lay off 500 people to adapt to changing market conditions, they were able to do so without interference from the community because of their favorable reputation, while layoffs by other firms elsewhere were met with unrest and angst.

\section{Building reputation}

Our theory also managerial implications for firms hoping to build reputation in emerging market settings. Given the importance of reputation for firm outcomes, understanding how reputation is built has direct implications for firm strategy. However, research on how firms develop reputation is surprisingly underdeveloped. Our theory suggests that, in emerging markets, firms might benefit from a reputation not only for producing quality products, but also for withstanding environmental shocks. This implies three general—though not mutually exclusive nor collectively exhaustive-approaches for firms without reputation to attain reputation: (1) through serendipity; (2) through providing a solution to a pressing need (thereby filling an institutional void); or (3) through partnerships. Further research elucidating and testing these mechanisms can have important implications for knowledge on firm strategy in emerging markets.

\section{Building reputation through serendipity}


In developed markets, firms without reputation can build up reputation by performing well—that is, demonstrating their quality—in certification contests (Rao, 1994). However, the challenge for firms trying to build reputation in emerging markets is that these settings lack precisely the information analyzers and certifiers that can credibly evaluate and rate firms (Khanna and Palepu, 2010). Moreover, in these settings, having high quality products is not enough: firms must also engender beliefs in their ability to persistently deliver such quality in the face of a shifting environment. Our data suggest that one way firms attain and develop reputation is through serendipity: exogenous shocks that allow firms to demonstrate their adherence to promises, and their ability to survive despite uncertainty. For instance, in the Godrej example, the Bombay mine explosion was a major news event, and because Godrej's safe was the only safe that survived the explosion, it allowed the firm to not only gain salience (being known), but also become known for resilience (the ability to survive shocks). The channel for acquiring salience and demonstrating quality here is the prominence of the exogenous news event: a mine explosion that gained the attention of many stakeholders. We see great potential for future research to explore the role of luck in building reputation and engendering success and survival in emerging market settings.

\section{Solution-driven approach: Filling institutional voids}

While we propose that a favorable reputation can help firms overcome institutional voids, our theory also suggests that filling an institutional void can be another general approach that helps firms build reputation. Because institutional voids affect a large number of stakeholders, a firm that fills a void will likely gain the stakeholders' attention. And because filling the void will also require adherence to promises and stability, it will likely build and influence stakeholders' perceptions about the firm's potential for future survival.

One example of this from our interviews is provided by BRAC, the Bangladeshibased organization that is now the world's largest NGO. BRAC acquired a reputation in the 
economic development community for being a judicious steward of funds and an entity that would credibly deliver on its promises. The formation of this reputation goes back to the organization's founding. In the early 1970s, as the area that is now known as Bangladesh reeled from a devastating cyclone in 1970 and a formal separation from Pakistan in 1971, BRAC's founder, the former head of Shell in the region, obtained a grant from the British foundation, Oxfam, to build houses for rehabilitation purposes. He ensured that his small team over-delivered on his promises by building more houses than promised and by offering to return unused money. Since then, BRAC has invested over more than four decades in being seen, among other things, as a credible entity. In the emerging markets environment where it is hard to assess the credibility of potential arms-length transaction partners, BRAC acquired a reputation by filling this institutional void that transcends conventional industry boundaries.

\section{Partnership-driven approach}

A third general approach to building reputation might be through leveraging the existing reputation of an established firm to use for one's own benefit, including through a mutual arrangement such as an affiliation or alliance. For example, when Sundram Fasteners was launched from scratch, its founder leveraged its affiliation with the reputable TVS Group, reminding every counterparty he interacted with that his venture was affiliated with TVS, which provided the founder great access to potential suppliers and customers. Prior research has suggested that new firms can build reputation by partnering with multiple, wellestablished firms (e.g. Stuart et al., 1999). We propose that doing so might be especially important in emerging market contexts, where affiliation can signal that a firm is likely to keep its promises and is likely to survive environmental maleficence. However, the difficulty of this approach is that acquiring affiliation and partnership with reputed establishment firms is not a trivial matter (since establishment firms often have little incentive to affiliate with an 
unknown entity). In our data, for example, we observe that reputation-building affiliations and partnerships are often driven by kinship ties.

\section{Cumulative effects of building reputation}

More generally, our theory suggests that firms in emerging markets should prioritize building reputation as a strategic objective early in their development. The cumulative effects of reputation suggest timing is particularly important: once a firm has a stock of reputation, it becomes easier to develop even more reputation. While we outlined above three general approaches for acquiring reputation, each approach is challenging. Luck is unpredictable and hard to plan for, filling an institutional void is inherently complicated (if it were easy, there

wouldn't be a void), and getting a reputable firm to commit to a partnership is difficult (since it requires an agreement where both parties have aligned incentives). Thus, because it is difficult to acquire reputation, and since reputation is socially complex and thus needs to be cultivated over time, having an early start might be key. We see great scope for future research to further unpack and integrate these divergent approaches.

\section{OPPORTUNITIES FOR RESEARCH}

The purpose of our study was building theory; we hope that improvements in the availability and quality of data will eventually allow scholars to empirically test our theoretical propositions. Our study cannot reliably dismiss all possible alternative explanations (for instance, the existence of processes or mechanisms driving both reputation and longevity), and cannot entirely account for potential endogeneity or reverse causality. To test the proposition that reputation is a meta-resource, empirical studies in institutionally-weak environments should interact a firm's reputation measure with its measure of conventional resources in estimating performance, while controlling for alternative explanations and reverse causality. We propose that the coefficient on the interaction term should be positive. 
We also hope future research will build on and extend our ideas. First, we do not explore the potential downsides of favorable reputation, or the potential benefits of a negative reputation. Future studies could explore whether firms with negative reputations can navigate institutional voids in alternative ways (for instance, through crony capitalism) to achieve the same outcomes (for instance, accessing capital from the state instead of markets (Leuz and Oberholzer-Gee, 2006)). Second, we do not consider what occurs when a firm has a different reputation among different stakeholders: for example, a positive reputation with consumers and suppliers, but a negative one with environmental activists. We thus see the development of a deeper understanding of the "liability of reputation" (Pfarrer et al., 2010; Rhee and Haunschild, 2006), and the relationship between favorable and non-favorable reputations in emerging markets, as important areas for future research. Third, because our data was constructed through theoretical sampling, we cannot examine whether there are firms that have survived over the long run despite lacking strong favorable reputations, and whether there are firms that failed in spite of possessing strong favorable reputations. Future research can further refine our theory by examining instances where a favorable reputation did not forestall failure, and the lack of favorable reputation did not constrain success.

Additionally, while we propose that reputation can be broken into three component factors - prominence, perceptions of quality, and resilience-we cannot separate their isolated effects on a firm's overall reputation, or on its long-term survival. Many of the respondents emphasized the importance of the cumulative, reinforcing nature of these components in driving long-run survival. In theorizing the effects of reputation as a cohesive construct, we thus follow qualitative studies that aggregate multiple codes into an overarching construct that serves as the basis for theorizing (e.g. Huy, 2011; Fauchart and Grueber, 2011). Reputation's components are likely reinforcing, and characterized by nonlinear relationships such as self-reinforcing feedback loops. Moreover, stakeholder action 
may be driven by their overall, aggregate perceptions of a firm. Nonetheless, we hope our propositions can motivate future studies testing the impact and relative importance of each component, and on disentangling their complex relationships. When, if ever, will resilience matter more than prominence and perceptions of quality? Does this vary across the stages in a firm's, industry's, or emerging market's state of development?

Finally, by considering only emerging market settings, we do not explicitly theorize the comparative effects of reputation in emerging versus mature markets. The idea of reputation as a meta-resource is consistent with studies in mature markets showing that reputation can help a firm realize the potential of its other resources (e.g. Dollinger, Golden, and Saxton, 1997; Stuart et al., 1999; Turban and Cable, 2003; Love and Kraatz, 2009; Stern et al., 2014). Nonetheless, our model suggests that reputation's ability to mitigate and capitalize on institutional voids would be significantly less transparent (and at the theoretical extreme, even redundant) in developed markets, where mature market institutions (such as information analyzers, credibility enhancers, functional adjudication mechanisms, ex-post watchdogs et cetera) reduce the risks of transacting with unknown parties. Structurally, this suggests that the greater the extent and degree of institutional voids in an environment, the greater the upside of reputation's meta-resource effects will be. We see potential for largescale quantitative studies to compare the effects of reputation on survival or performance in emerging markets and in more developed settings.

We thus shed light on the importance of an underappreciated construct (reputation) in an under-theorized setting (emerging markets) over an unusual period (the long run), in the hopes of motivating future research. Given the fluctuations of successes and failures in modern emerging economies, the increasing interdependence between emerging and developed economies, and the lack of theory beyond developed market settings (Bettis et al., 2014), developing academic theory on how success can be attained and sustained in 
institutionally-underdeveloped environments has never been more important. We hope our proposed theory is a first step in motivating further research and practice in this vein. 


\section{REFERENCES:}

Data Citation:

"Creating Emerging Markets" project, Business History Initiative, Harvard Business School. Publicly Accessible. URL: http://www.hbs.edu/businesshistory/emergingmarkets/Pages/default.aspx

References:

Agarwal R, Helfat CE. 2009. Strategic renewal of organizations. Organization Science 20(2): 281-293.

Ahuja G, Yayavaram S. 2011. Explaining Influence Rents: The Case for an InstitutionsBased View of Strategy. Organization Science, 22(6): 1631-1652.

Allen F. 1984. Reputation and product quality. The RAND Journal of Economics 15(3): 311 327.

Barney JB. 1991. Firm resources and sustained competitive advantage. Journal of Management 17(99): 99-120.

Basdeo DK, Smith KG, Grimm CM, Rindova VP, Derfus PJ. 2006. The impact of market actions on firm reputation. Strategic Management Journal, 27(12): 1205-1219.

Battilana J, Dorado S. 2010. Building sustainable hybrid organizations: The case of commercial microfinance organizations. Academy of Management Journal, 53(6): 14191440.

Bermiss YS, Zajac EJ, King BG. 2013. Under construction: how commensuration and management fashion affect corporate reputation rankings. Organization Science 25(2): 591608.

Bettis RA, Gambardella A, Helfat C, Mitchell W. 2014. Theory in strategic management. Strategic Management Journal 35(10): 1411-1413.

Brown CO, Dinc IS. 2005. The politics of bank failures: evidence from emerging markets. The Quarterly Journal of Economics 120(4): 1413-1444.

Charmaz K. 2014. Constructing grounded theory. Sage: London.

Choi SJ, Jia N, Lu J. 2014. The structure of political institutions and effectiveness of corporate political lobbying. Organization Science 26(1): 158-179.

Clark BH, Montgomery DB. 1998. Deterrence, reputations, and competitive cognition. Management Science 44(1), 62-82.

Connell CM. 2004. A Business in Risk: Jardine Matheson and the Hong Kong Trading Industry. Greenwood Publishing Group: Westport, CT.

Corbin J, Strauss A. 2008. Basics of qualitative research 3e. SAGE Publications: New York.

Dollinger MJ, Golden PA, Saxton T. 1997. The effect of reputation on the decision to joint venture. Strategic Management Journal 18(2): 127-140.

Dougherty D, Hardy C. 1996. Sustained product innovation in large, mature organizations: Overcoming innovation-to-organization problems. Academy of Management Journal 39(5): 1120-1153.

Douma S, George R, Kabir R. 2006. Foreign and domestic ownership, business groups, and firm performance: Evidence from a large emerging market. Strategic Management Journal 27(7): 637-657.

Edmondson AC, McManus SE. 2007. Methodological fit in management field research. Academy of Management Review, 32(4): 1246-1264.

Eisenhardt KM, Graebner ME. 2007. Theory building from cases: opportunities and challenges. Academy of Management Journal, 50: 25-32.

Eisenhardt, K. M., Graebner, M. E., Sonenshein, S. 2016. Grand Challenges and Inductive Methods: Rigor without Rigor Mortis. Academy of Management Journal, 59(4), 1113-1123. 
Eisenhardt KM, Martin JA. 2000. Dynamic capabilities: what are they?. Strategic Management Journal 21(10-11): 1105-1121.

Evans, J. A., \& Foster, J. G. (2011). Metaknowledge. Science, 331(6018), 721-725.

Fauchart E, Gruber M. 2011. Darwinians, communitarians, and missionaries: The role of founder identity in entrepreneurship. Academy of management journal 54(5): 935-957.

Feldman, M.S. and Pentland, B.T., 2003. Reconceptualizing organizational routines as a source of flexibility and change. Administrative science quarterly, 48(1), pp.94-118.

Flanagan DJ, O'Shaughnessy KC. The effect of layoffs on firm reputation. Journal of Management 31(3): 445-463.

Fombrun C, Shanley M. 1990. What's in a name? Reputation building and corporate strategy. Academy of Management Journal 33(2): 233-258.

García-Canal E, Guillén MF. 2008. Risk and the strategy of foreign location choice in regulated industries. Strategic Management Journal 29(10): 1097-1115.

Gavetti G, Rivkin JW. 2007. On the origin of strategy: action and cognition over time. Organization Science 18(3): 420-439.

Ghemawat P. 2007. Redefining Global Strategy: Crossing Borders in a World Where Differences Still Matter. Harvard Business Press: Boston, MA.

Ghemawat P, Khanna T. 1998. The nature of diversified business groups: A research design and two case studies. The Journal of Industrial Economics, 46(1): 35-61.

Ghemawat P, Siegel JI. 2011. Cases about Redefining Global Strategy. Harvard Business

Publishing.

Golden BR. 1992. The past is the past-or is it? The use of retrospective accounts as indicators of past strategy. Academy of Management Journal 35(4): 848-860.

Guillen MF. 2000. Business groups in emerging economies: a resource-based view. Academy of Management Journal 43(3): 362-380.

Hall R. 1993. A framework linking intangible resources and capabilities to sustainable competitive advantage. Strategic Management Journal 14(8): 607-618.

Helfat CE, Finkelstein S, Mitchell W, Peteraf M, Singh H, Teece D, Winter SG. 2009. Dynamic capabilities: Understanding strategic change in organizations. Blackwell Publishing: Malden, MA.

Helfat CE, Peteraf MA. 2003. The dynamic resource-based view: Capability lifecycles. Strategic Management Journal, 24(10): 997-1010.

Henisz WJ, Dorobantu S, Nartey LJ. 2014. Spinning gold: the financial returns to stakeholder engagement. Strategic Management Journal 35(12): 1727-1748.

Herbig P, Milewicz J. 1995. The relationship of reputation and credibility to brand success. Journal of Consumer Marketing 12(4): 5-10.

Hiatt SR, Sine WD. 2014. Clear and present danger: Planning and new venture survival amid political and civil violence. Strategic Management Journal 35: 773-785.

Hoskisson RE, Eden L, Lau CM, Wright M. 2000. Strategy in emerging economies. Academy of Management Journal 43(3): 249-267.

Huy QN. 2011. How middle managers' group-focus emotions and social identities influence strategy implementation. Strategic Management Journal 32(13): 1387-1410.

Ingram PL, Silverman BS. 2002. The new institutionalism in strategic management. Elsevier: Kidlington.

Jones G. 2000. Merchants to Multinationals. Oxford University Press: New York, NY.

Jones G. 2005. Multinationals and Global Capitalism: From the Nineteenth to the TwentyFirst Century. Oxford University Press: New York, NY.

Jones G. 2013. Entrepreneurship and Multinationals: Global Business and the Making of the Modern World. Edward Elgar Publishing: Northampton, MA. 
Jones G, Khanna T. 2006. Bringing History (Back) into International Business. Journal of International Business Studies 37(4): 453-468.

Khanna T. 2014. Contextual Intelligence. Harvard Business Review 92(9): 58-68.

Khanna T, Palepu KG. 1997. Why focused strategies may be wrong for emerging markets. Harvard Business Review 75(4): 41-51.

Khanna T, Palepu KG. 1999. Policy Shocks, Market Intermediaries, and Corporate Strategy: The Evolution of Business Groups in Chile and India. Journal of Economics \& Management Strategy 8(2): 271-310.

Khanna T, Palepu KG. 2004. Globalization and convergence in corporate governance: evidence from Infosys and the Indian software industry. Journal of International Business Studies 35(6): 484-507.

Khanna T, Palepu KG. 2010. Winning in Emerging Markets: A Road Map for Strategy and Execution. Harvard Business Review Press: Boston, MA.

Khanna T, Palepu KG, Herrero GA. 2007. Tetra Pak Argentina. Harvard Business School Case 708-402.

Khanna T, Rivkin J. 2001. Estimating the performance effects of business groups in emerging markets. Strategic Management Journal 22(1): 45-74.

Khanna T, Yafeh Y. 2007. Business groups in emerging markets: paragons or parasites?. Journal of Economic Literature 45(2): 331-372.

Kobrak C. 2013. The concept of reputation in business history. Business History Review 87(04): 763-786.

Kram KE. 1983. Phases of the mentor relationship. Academy of Management Journal 26(4): 608-625.

Leuz C, Oberholzer-Gee F. 2006. Political relationships, global financing, and corporate transparency: Evidence from Indonesia. Journal of Financial Economics 81(2): 411-439.

Lounsbury M, Glynn MA. 2001. Cultural entrepreneurship: stories, legitimacy, and the acquisition of resources. Strategic Management Journal 22(6-7), 545-564.

Love EG, Kraatz M. 2009. Character, conformity, or the bottom line? How and why downsizing affected corporate reputation. Academy of Management Journal 52(2): 314335.

Luo XR, Chung CN. 2005. Keeping it all in the family: The role of particularistic relationships in business group performance during institutional transition. Administrative Science Quarterly 50(3): 404-439.

Luo XR, Chung CN. 2013. Filling or abusing the institutional void? Ownership and management control of public family businesses in an emerging market. Organization Science 24(2): 591-613.

Mair J, Martí I, Ventresca MJ. 2012. Building inclusive markets in rural Bangladesh: How intermediaries work institutional voids. Academy of Management Journal 55(4): 819-850.

Marquis C, Qian C. 2013. Corporate social responsibility reporting in China: Symbol or substance? Organization Science 25(1): 127-148.

Marquis C, Raynard M. 2015. Institutional Strategies in Emerging Markets. Academy of Management Annals 9(1): 291-335.

McKenna C, Olegario R. 2012. Corporate reputation and regulation in historical perspective. In The Oxford Handbook of Corporate Reputation, Barnett ML, Pollock TG (eds). Oxford University Press: Oxford, UK.

Meyer KE, Estrin S, Bhaumik SK, Peng MW. 2009. Institutions, resources, and entry strategies in emerging economies. Strategic Management Journal 30(1): 61-80.

Moorthy K.S. 1985. Using game theory to model competition. Journal of Marketing 22(3): 262-282. 
Morck, R., Wolfenzon, D., Yeung, B. 2005. Corporate governance, economic entrenchment, and growth. Journal of Economic Literature, 43(3), 655-720.

Olegario R, McKenna C. 2013. Introduction: corporate reputation in historical perspective. Business History Review 87(4), 643-654.

O'Reilly CA, Tushman ML. 2008. Ambidexterity as a dynamic capability: Resolving the innovator's dilemma. Research in Organizational Behavior 28: 185-206.

Pak, SJ. 2013. Gentlemen Bankers: The World of J. P. Morgan. Harvard University Press: Boston, MA.

Peng MW, Sun SL, Pinkham B, Chen H. 2009. The institution-based view as a third leg for a strategy tripod. Academy of Management Perspectives 23(3): 63-81.

Peteraf MA. 1993. The cornerstones of competitive advantage: a resource-based view. Strategic Management Journal 14(3): 179-191.

Pfarrer MD, Pollock TG, Rindova VP. 2010. A tale of two assets: the effects of firm reputation and celebrity on earnings surprises and investors' reactions. Academy of Management Journal 53(5): 1131-1152.

Pollock TG, Rindova VP. 2003. Media legitimation effects in the market for initial public offerings. Academy of Management Journal 46(5): 631-642.

Pratt MG. 2009. From the editors: For the lack of a boilerplate: Tips on writing up (and reviewing) qualitative research. Academy of Management Journal, 52(5): 856-862.

Rao H. 1994. The social construction of reputation: certification contests, legitimation, and the survival of organizations in the American automobile industry: 1895-1912. Strategic Management Journal, 15(S1), 29-44.

Raub W, Weesie J. 1990. Reputation and efficiency in social interactions: an example of network effects. American Journal of Sociology 96(3): 626-654.

Rhee M, Haunschild PR. 2006. The liability of good reputation: A study of product recalls in the US automobile industry. Organization Science 17(1), 101-117.

Rindova VP, Kotha S. 2001. Continuous "morphing": Competing through dynamic capabilities, form, and function. Academy of Management Journal 44(6): 1263-1280.

Rindova VP, Pollock TG, Hayward ML. 2006. Celebrity firms: the social construction of market popularity. Academy of Management Review 31(1), 50-71.

Rindova VP, Williamson IO, Petkova AP, Sever JM. 2005. Being good or being known: an empirical examination of the dimensions, antecedents, and consequences of organizational reputation. Academy of Management Journal 48(6), 1033-1049.

Roberts PW, Dowling GR. 2002. Corporate reputation and sustained superior financial performance. Strategic Management Journal. 23(12): 1077-1093.

Santos, F. M., \& Eisenhardt, K. M. 2009. Constructing markets and shaping boundaries: Entrepreneurial power in nascent fields. Academy of Management Journal, 52(4), 643-671.

Shapiro C. 1983. Premiums for high quality products as returns to reputations. The Quarterly Journal of Economics 98(4): 659-679.

Shi WS, Markóczy L, Stan CV. 2014. The continuing importance of political ties in China. The Academy of Management Perspectives 28(1), 57-75.

Siegel J. 2007. Contingent political capital and international alliances: evidence from South Korea. Administrative Science Quarterly 52(4), 621-666.

Sorenson O. 2014. Status and reputation: Synonyms or separate concepts?. Strategic Organization 12(1): 62-69.

Staw BM, Epstein LD. 2000. What bandwagons bring: effects of popular management techniques on corporate performance, reputation, and CEO pay. Administrative Science Quarterly 45(3): 523-556.

Stern I, Dukerich JM, Zajac E. 2014. Unmixed signals: how reputation and status affect alliance formation. Strategic Management Journal 35(4): 512-531. 
Stuart TE, Hoang H, Hybels RC. 1999. Interorganizational endorsements and the performance of entrepreneurial ventures. Administrative Science Quarterly 44(2): 315-349.

Tan J, Peng MW. 2003. Organizational slack and firm performance during economic transitions: Two studies from an emerging economy. Strategic Management Journal, 24(13): 1249-1263.

Teece DJ, Pisano G, Shuen A. 1997. Dynamic capabilities and strategic management. Strategic Management Journal 18(7): 509-533.

Turban DB, Cable DM. 2003. Firm reputation and applicant pool characteristics. Journal of Organizational Behavior 24(6): 733-751.

van Agtmael A. 2007. The Emerging Markets Century: How a New Breed of World-Class Companies is Overtaking the World. Free Press: New York, NY.

Weigelt K, Camerer C. 1988. Reputation and corporate strategy: a review of recent theory and applications. Strategic Management Journal 9(5), 443-454.

Wernerfelt B. 1984. A resource-based view of the firm. Strategic Management Journal 5(2): 171-180.

Williamson OE. 1981. The economics of organization: The transaction cost approach. American Journal of Sociology, 548-577.

Zhu H, Chung CN. 2014. Portfolios of Political Ties and Business Group Strategy in Emerging Economies Evidence from Taiwan. Administrative Science Quarterly 59(4): 599-638.

Zuckerman EW. 1999. The categorical imperative: Securities analysts and the illegitimacy discount. American Journal of Sociology 104(5): 1398-1438. 
Figure 1. Proposed anatomy of reputation as a meta-resource in emerging markets

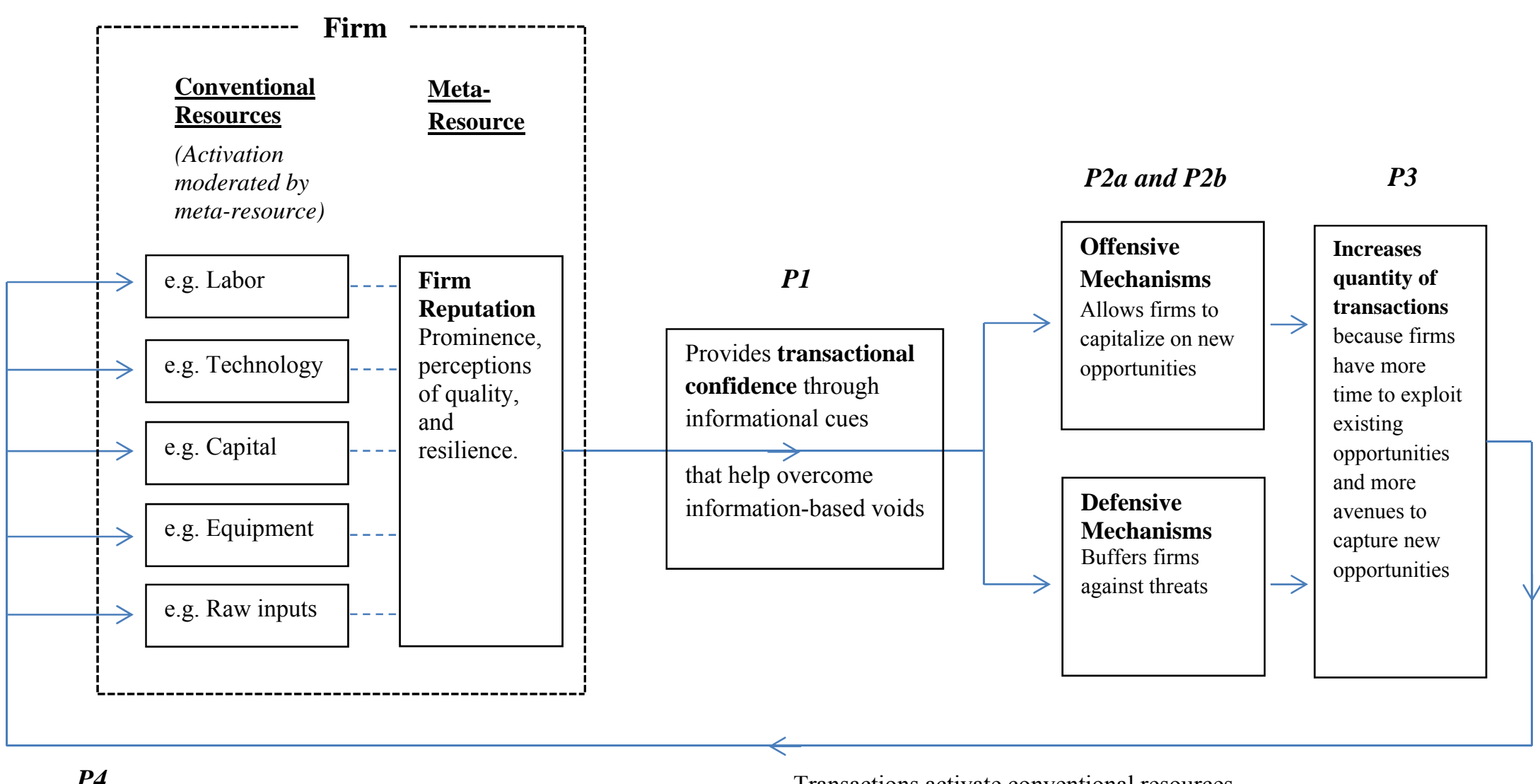

P4

Transactions activate conventional resources

Time (Cumulative effects and sustained advantage)

P5 
[ONLINE SUPPLEMENT] Appendix 1: Interviews analyzed and summary statistics

\begin{tabular}{|c|c|c|c|}
\hline Name & Position & Industry & Country \\
\hline Kwasi Abeasi & CEO, Africa Investconsult Ltd. & Financial Services & Ghana \\
\hline Fazle Hasan Abed & Founder and Chair, BRAC & $\begin{array}{l}\text { Microfinance, } \\
\text { Development }\end{array}$ & Bangladesh \\
\hline Arturo Acevedo & President, Grupo ArcelorMittal-Acindar & Steel, Mining & Argentina \\
\hline Abbas Akbarally & Chairman, Akbar Brothers & Diversified & Sri Lanka \\
\hline Hamdi Akin & Founder and Chairman, Akfen Holding & $\begin{array}{l}\text { Construction, } \\
\text { infrastructure }\end{array}$ & Turkey \\
\hline Roberto de Andraca & Chairman, Cap S.A. & Steel & Chile \\
\hline Roberto Angelini Rossi & Chairman, Empresas Copec S.A. and AntarChile S.A. & $\begin{array}{l}\text { Petroleum, Forestry, } \\
\text { Fishing }\end{array}$ & Chile \\
\hline Gülsüm Azeri & $\begin{array}{l}\text { Group President, Şişecam; CEO, OMV Petrol Ofisi } \\
\text { (current) }\end{array}$ & $\begin{array}{l}\text { Chemicals and glass; } \\
\text { Petroleum }\end{array}$ & Turkey \\
\hline Alberto Bailleres & CEO, Grupo Bal & Diversified & Mexico \\
\hline Rahul Bajaj & Chairman, Bajaj Group & Diversified & India \\
\hline Hakeem Belo-Osagie & $\begin{array}{l}\text { Chair, United Bank for Africa (currently with Etisalat } \\
\text { Nigeria) }\end{array}$ & Financial services & Nigeria \\
\hline $\begin{array}{l}\text { Alberto Benavides de la } \\
\text { Quintana }\end{array}$ & $\begin{array}{l}\text { Founder and Chairman, Compañía de Minas } \\
\text { Buenaventura }\end{array}$ & Mining & Peru \\
\hline Jorge Born & Former President, Bunge y Born (now Bunge Limited) & Agribusiness, Food & Argentina \\
\hline Cem Boyner & CEO, Boyner Holding & Retail & Turkey \\
\hline Federico Braun & $\begin{array}{l}\text { President and Chairman, Sociedad Anónima Importadora } \\
\text { y Exportadora de la Patagonia (SAIEP) (La Anónima) }\end{array}$ & Supermarkets & Argentina \\
\hline Manu Chandaria & Chairman and CEO, Comcraft Group & Steel and Aluminum & Kenya \\
\hline Ricardo Claro & $\begin{array}{l}\text { Chairman, Claro Group (defunct; main company, } \\
\text { Compañia Sud Americana de Vapores S.A.) }\end{array}$ & Shipping & Chile \\
\hline Nalli Kuppuswami Chetti & Chairman, Nalli Silk Sarees & Textiles, retail & India \\
\hline Paulo A. Cunha & Chair, Grupo Ultra & $\begin{array}{l}\text { Petroleum and Natural } \\
\text { Gas; Chemicals }\end{array}$ & Brazil \\
\hline $\begin{array}{l}\text { Felipe Antonio (Tony) } \\
\text { Custer }\end{array}$ & CEO, Corporacion Custer & Food, Chemicals & Peru \\
\hline Hubert Danso & CEO and Vice Chairman, Africa Investor & $\begin{array}{l}\text { Financial Services, } \\
\text { Media }\end{array}$ & $\begin{array}{l}\text { South } \\
\text { Africa }\end{array}$ \\
\hline William Engels & Member of the Board, Bunge Limited & Agribusiness & Argentina \\
\hline Andre Esteves & CEO, BTG Pactual & Financial Services & Brazil \\
\hline Dionisio Garza Medina & Former President and CEO, Alfa S.A.B. de C.V. & Diversified & Mexico \\
\hline Jorge Gerdau Johannpeter & $\begin{array}{l}\text { Chairman, Gerdau Advisory Council; former CEO, } \\
\text { Grupo Gerdau }\end{array}$ & Steel & Brazil \\
\hline Adi Godrej & Chairman, Godrej Group & Diversified & India \\
\hline Jose Grana Miró Quesada & Chairman, Graña y Montero & Construction, Real Estate & Peru \\
\hline Rafael Guilisasti Gana & Vice Chairman, Vina Concha y Toro S.A. & Wine & Chile \\
\hline Yusuf Hamied & CEO, Cipla & Pharmaceuticals & India \\
\hline Tomás Hudson & $\begin{array}{l}\text { President, Imperial Chemical Industries (ICI) (now part } \\
\text { of Akzo Nobel) }\end{array}$ & Chemicals & Argentina \\
\hline Ranjan Kapur & Executive Chairman, Ogilvy \& Mather India & Advertising & India \\
\hline Rahmi M. Koc & Honorary Chairman, Koç Holding & Diversified & Turkey \\
\hline Suresh Krishna & Chairman, Sundram Fasteners & Metal products & India \\
\hline Ritu Kumar & Founder, Ritika Private Limited & Fashion, textiles, retail & India \\
\hline Amalia Lacroze de Fortabat & $\begin{array}{l}\text { President and Chair, Loma Negra Cia Industrial } \\
\text { Argentina S.A. (Now belongs to other investors) }\end{array}$ & Cement & Argentina \\
\hline Agustin Legorreta & Former President, Banco Nacional de Mexico & Financial Services & Mexico \\
\hline Erling Lorentzen & Former CEO, Aracruz Celulose & Pulp and Paper & Brazil \\
\hline Andrónico Luksic Craig & Vice Chairman, Banco de Chile and Quiñenco S.A. & Banking, Mining & Chile \\
\hline Antonio Madero & Founder and CEO, SANLUIS Corporación S.A. de C.V & Automotive Parts & Mexico \\
\hline Jorge Marín Correa & President, Compañía General de Electricidad s.a. (cge) & Electricity, Natural Gas & Chile \\
\hline Keshub Mahindra & Former Chairman, Mahindra Group & Diversified & India \\
\hline Carlos Wizard Martins & Founder, Grupo Multi & Education & Brazil \\
\hline
\end{tabular}




\begin{tabular}{|c|c|c|c|}
\hline Name (continued) & Position (continued) & Industry (continued) & Country \\
\hline Savannah Maziya & $\begin{array}{l}\text { CEO, Bunengi Holdings; Chair, Parsons Brinckerhoff } \\
\text { Africa }\end{array}$ & Infrastructure, Mining & $\begin{array}{l}\text { South } \\
\text { Africa }\end{array}$ \\
\hline Eliodoro Matte Larraín & President, Empresas CMPC S.A. & Pulp and Paper & Chile \\
\hline Eva Muraya & Group CEO, Brand Strategy and Design Ltd & $\begin{array}{l}\text { Advertising and } \\
\text { Marketing }\end{array}$ & Kenya \\
\hline Guillermo Murchison & CEO, Murchison, Estibajes y Cargas S.A. & Shipping and Logistics & Argentina \\
\hline Prithvi Raj Singh Oberoi & Executive Chairman, EIH Limited & Hospitality, Tourism & India \\
\hline Victor Gbolade Osibodu & Chairman and CEO, Vigeo Limited & Diversified & Nigeria \\
\hline Husnu Ozyegin & Chairman, FIBA Holding & Financial Services & Turkey \\
\hline Luis Alejandro Pagani & CEO, Grupo Arcor & Food Production & Argentina \\
\hline Horst Paulmann Kemna & President, Cencosud S.A. & Retail & Chile \\
\hline Nii Quaynor & Chair, Network Computer Systems and Ghana Dot Com & Internet Provider & Ghana \\
\hline Prathap Reddy & Founder and Chairperson, Apollo Hospitals & Healthcare & India \\
\hline Guler Sabanci & Chair, Sabanc1 Holding & Diversified & Turkey \\
\hline Manuel Sacerdote & Regional President, BankBoston (Argentina) (now ICBC) & Financial Services & Argentina \\
\hline Ricardo Salinas Pliego & CEO, Grupo Salinas & Diversified & Mexico \\
\hline Pedro Moreira Salles & Chair, Itaú Unibanco & Financial Services & Brazil \\
\hline Daniel Servitje Montull & CEO, Grupo Bimbo & Food Production & Mexico \\
\hline Roberto Setubal & President and CEO, Itaú Unibanco & Financial Services & Brazil \\
\hline Reinaldo Solari & Chairman, S.A.C.I. Falabella & Retail & Chile \\
\hline Ratan Naval Tata & Chairman, Tata Trust; Former Chairman, Tata Group & Diversified & India \\
\hline Luiza Helena Trajano & President, Magazine Luiza & Retail & Brazil \\
\hline Murat Vargi & Founder and Chair, MV Holding & Diversified & Turkey \\
\hline Rodolfo Viegener & $\begin{array}{l}\text { Former President, FV S.A.; Former Chairman and CEO, } \\
\text { Ferrum S.A. }\end{array}$ & $\begin{array}{l}\text { Faucets and plumbing } \\
\text { products }\end{array}$ & Argentina \\
\hline Sven Von Appen & Chairman, Ultramar Agencia Maritima & Shipping and Logistics & Chile \\
\hline $\begin{array}{l}\text { Gordon \& Morine } \\
\text { Wavamunno }\end{array}$ & $\begin{array}{l}\text { Chairman and CEO (Gordon) and Executive Director } \\
\text { (Morinne), Spear Group }\end{array}$ & Diversified & Uganda \\
\hline Julio Werthein & President, Grupo Werthein & Diversified & Argentina \\
\hline $\begin{array}{l}\text { Augusto Felipe Wiese de } \\
\text { Osma }\end{array}$ & CEO, Grupo Wiese & Diversified & Peru \\
\hline Selcuk Yasar & Founder and Honorary Chairman, Yaşar Holding & Diversified & Turkey \\
\hline
\end{tabular}

Note: Names listed in alphabetical order by surname; Spanish names ordered by first surname (apellido paterno). Analyzed interviews represent the complete set of all available interviews at time of analysis (January 2016); interviews are publicly available through the HBS Creating Emerging Markets Project (see full citation in references page).

\section{Summary statistics of interview data at time-of-interview*:}

\begin{tabular}{lll}
\hline Data & & \\
\hline Firms & Mean Age & 73 \\
& Median Age & 19 \\
& Max & 12 \\
\hline Respondents & Min & 69 \\
& Mean Age & 69 \\
& Median Age & 93 \\
Most represented countries & Max & 44 \\
& Min & 11 \\
& Argentina & 11 \\
& India & 10 \\
\hline Most represented industries & Chile & 8 \\
& Brazil & 8 \\
\hline
\end{tabular}

* Firm age estimates calculated based on firm founding year, discovered through archival research. In some cases, defining a precise firm founding year is difficult due to corporate development events or unclear origin markets. Thus, some founding years are approximations based on archival research findings. 


\section{[ONLINE SUPPLEMENT] Appendix 2: Subset of data structure}

\begin{tabular}{ll}
\hline First-Order Codes & Second-Order Themes \\
\hline Formal planning & Planned vs. emergent strategy \\
Emergence & \\
Luck & Adaptation \\
\hline New opportunities & \\
Change of action due to new & \\
information/circumstance & \\
New idea and practice & \\
New political activity & Sense-making \\
\hline Perceived mistake & \\
Perceived success & Learning \\
Perceived luck & \\
\hline Adaptive learning & \\
Business learning (early formative) & Reputation \\
Professionalization & \\
\hline Brand awareness / Prominence & \\
Quality of products/services & \\
Perceived stability/resilience &
\end{tabular}




\section{[ONLINE SUPPLEMENT] Appendix 3: Illustrative examples of coding of reputation}

\begin{tabular}{|c|c|c|}
\hline Interviewee & Quote & First-Order Code \\
\hline $\begin{array}{l}\text { Adi Godrej } \\
\text { Chairman, Godrej Group } \\
\text { (one of India's largest } \\
\text { diversified business } \\
\text { groups) }\end{array}$ & $\begin{array}{l}\text { "Fortunately, being in consumer products, if your brand is doing reasonably well, } \\
\text { and if it is growing, then you don't get affected by setbacks of other kinds...Many } \\
\text { Indian groups which were very strong say in the 1950s or in the } 1960 \text { s, some of } \\
\text { them almost disappeared because the socialist regime created difficulties for } \\
\text { growth... We were fortunate that the brand carried our success quite strongly" }\end{array}$ & Prominence \\
\hline $\begin{array}{l}\text { Sir Fazle Hasan Abed } \\
\text { Founder, Chairman, } \\
\text { BRAC } \\
\text { (largest NGO in the } \\
\text { world by number of } \\
\text { employees) }\end{array}$ & $\begin{array}{l}\text { "We have a reputation of being able to deliver whatever we promise, and that } \\
\text { helps us in also finding money in Africa to try and develop programs... As soon as } \\
\text { we went to Afghanistan [from Bangladesh] in } 2001 \text {, everybody flocked to fund } \\
\text { BRAC, because we had the reputation. And so we started getting funding from } \\
\text { sources that we didn't know, we didn't want, so all kinds of money started } \\
\text { flowing in. We became very quickly the largest NGO in Afghanistan." }\end{array}$ & Quality \\
\hline $\begin{array}{l}\text { Federico Braun } \\
\text { President of La Anónima } \\
\text { (one of Argentina's } \\
\text { largest supermarket } \\
\text { chains) }\end{array}$ & $\begin{array}{l}\text { "There are no mysteries in the supermarket business...In fact, in world retailing } \\
\text { history, innovations are quickly imitated...La Anónima is seen as a company that } \\
\text { meets its commitments, has longtime and loyal employees - and this is important } \\
\text { - and keeps its word. However simple they may seem, these qualities are not that } \\
\text { easy to find. I don't believe technology is a distinctive factor, like bar codes, or } \\
\text { scanning..." }\end{array}$ & Resilience \\
\hline $\begin{array}{l}\text { Jose Grana Miró Quesada } \\
\text { Chairman of Grana y } \\
\text { Montero (the oldest and } \\
\text { largest construction } \\
\text { company in Peru) }\end{array}$ & $\begin{array}{l}\text { "Considering that the company had already secured some success, we set out to } \\
\text { find the reasons underlying that success and to determine what we had to preserve } \\
\text { moving forward...So, we conducted a survey with our customers, workers and } \\
\text { suppliers... [and found that] clients relied on a company like Graña y Montero on } \\
\text { account of its reputation, because it was a serious business. That was something } \\
\text { we had missed... Our goal is not to be the largest or the richest, but rather the most } \\
\text { reliable company in the industry. Our surveys have shown that clients make no- } \\
\text { bid decisions based on reliability. And if you are the most reliable company, your } \\
\text { prestige will help you grow your business." }\end{array}$ & Resilience \\
\hline
\end{tabular}

